\title{
Sustainable Valorization of Halophytes from the Mediterranean Area: A Comprehensive Evaluation of Their Fatty Acid Profile and Implications for Human and Animal Nutrition
}

\author{
Catarina Vizetto-Duarte ${ }^{\circledR}$, Filipe Figueiredo, Maria João Rodrigues, Cristina Polo, Eva Rešek \\ and Luísa Custódio *(D) \\ Centre of Marine Sciences, University of Algarve, Ed. 7, Campus of Gambelas, 8005-139 Faro, Portugal; \\ catarina.vizetto@gmail.com (C.V.-D.); filipe.figueiredo@uit.no (F.F.); mary_p@sapo.pt (M.J.R.); \\ cristina.polo@gmail.com (C.P.); eva.resek@gmail.com (E.R.) \\ * Correspondence: lcustodio@ualg.pt
}

Received: 9 March 2019; Accepted: 9 April 2019; Published: 12 April 2019

\begin{abstract}
Halophytic plants can provide an economical and environmentally sustainable source of products for human and animal feeding, in the context of the increase of worldwide emergent semi-arid landscapes. This work reports a comprehensive evaluation of the qualitative and quantitative composition of fatty acids (FA) of nineteen Mediterranean halophytes collected in southern Portugal, with the purpose of establishing their possible uses as food and feed. For FA determination, lipids and free FA were converted to the corresponding fatty acid methyl esters (FAME) and analyzed by GC-MS. Beta maritima had the highest FAME levels $(7.3 \mathrm{mg} / \mathrm{g}$ DW) while Suaeda vera had the lowest content $(1.0 \mathrm{mg} / \mathrm{g}$ DW). The most common saturated fatty acid (SFA) across all studied species was palmitic acid. The most prevalent monounsaturated fatty acid (MUFA) was oleic acid. Polyunsaturated fatty acids (PUFA) levels were led by linoleic acid. Less common FAMEs were also detected, namely eicosadienoic and hexadecatrienoic acids. Cotula coronopifolia, Phragmites australis and Suaeda vera displayed the best FA nutritional profiles. These species also showed bioactivities relevant for both human and animal health according to the literature and thus, collectively with this study, they could be further explored as food and feed.
\end{abstract}

Keywords: fatty acids; feed; food; halophytes; PUFA

\section{Introduction}

Underutilization of natural resources and food insecurity remains a significant challenge for the governments of the Mediterranean countries [1]. In this area, approximately 18 million ha, corresponding to $25 \%$ of the total irrigated land are salt-affected [2]. Within the European Union, Portugal is the country most affected by desertification, followed by Turkey and Italy, with a third of its territory affected and rapidly increasing in the next two decades [3]. Hence, there has been a growing interest in the use of arid and saline soils for food and/or feed production.

Halophytes represent about $1 \%$ of the world's flora and are found in salt deserts and saline areas such as beaches, salt marshes and mangroves [4]. While the majority of the crop and forage species used in modern agriculture are salt sensitive (glycophytes) and can handle only a very limited concentration of salt in their growth media, the growth of several halophytes is stimulated within a salinity range of 15-25 dSm [5]. In fact, halophytes can tolerate a wide range of salinities, even beyond seawater concentration (approx. $500 \mathrm{mM} \mathrm{NaCl}$ ), and can withstand harsh conditions, as for example drought and intense UV radiation [6-8]. 
Several halophytes are edible and have been used as food in Europe throughout the centuries, as for example Salicornia species, which is also called sea asparagus [9]. Some species are highly procured by the food industry nowadays due to their organoleptic and nutritional properties. This is the case for Chenopodium quinoa Willd. and Crithmum maritimum L., which have a great commercial value and are highly valued in gourmet cuisine. Moreover, several halophyte species present antioxidant, anti-inflammatory, antidiabetic or neuroprotective medicinal properties [9], which make halophyte plants even more interesting to explore on a nutritional and nutraceutical view. Finally, many of these species, as for example Sporobolus sp. and Distichlis sp. offer a valuable reserve feed for grazing animals especially under drought conditions or can be used to fill regular gaps in feed supply caused by seasonal conditions [10]. These plants may thus constitute a major part of the feeding program of, for example, sheep, goats and camels in the arid and semi-arid regions of the Mediterranean [10].

Fatty acids (FA) are long chained carboxylic acids present in all organisms. They are indispensable as energy sources, and as nutrients for survival and growth [11]. They can be divided, according to the number of double bonds present in their carbon chain, into saturated (SFA), monounsaturated (MUFA) and polyunsaturated (PUFA). PUFAs are implicated in different mechanisms that contribute to human health improvements, such as the prevention of inflammatory processes, reduction of the incidence of coronary diseases and cancer and blood pressure control [11,12]. PUFAs, especially the n-3 long docosahexaenoic acid (DHA) and n-6 arachidonic acid (AA), are vital for the proper growth and development of the brain of the developing foetus during pregnancy [13]. In humans, as in other animals, PUFAs also have an important role as a source of energy and are critical components of the physical and functional structure of cells, contributing to the overall health status. Besides, linoleic acid (LA, 18:2n-6), $\alpha$-linolenic acid (ALA, C18:3n-3), eicosapentaenoic acid (EPA, C20:5n-3) and DHA may target reproductive tissues and alter reproductive function and fertility, and are therefore critical nutrients, used to improve male reproductive performance in ruminants [14]. As vertebrates are unable to synthesize ALA and LA, these PUFA are among the most important required in both food and feed, and thus they must be obtained through diet [15]. Moreover, the nutritional intake of n-3 PUFA has shown to have clinical benefits in autoimmune disorders, both in animal and human studies [16].

Despite the interest in the use of halophytes as alternative cash crops in the context of climate change and salinization raise [6], studies regarding their potential as food and/or feed are scarce, especially concerning their FA content [17-21]. Aiming to fulfil this gap, this work analysed the FA content and profile of 19 species of wild halophytes collected from saline areas in the South of Portugal. In addition, the potential application of the halophytes under study as food and feed is discussed, along with the advantage and practical application of our findings.

\section{Materials and Methods}

\subsection{Sampling Procedure and Processing of Biomass}

Target species were selected based on their ethnomedicinal and ethnoveterinary uses and abundance in the area of collection. Aerial parts were collected during June 2010 in the south coast of Portugal (Algarve), and species were identified by Dr M. J. Pinto from the Museum of Natural History (Faculty of Sciences of the University of Lisbon). Nineteen species were sampled, belonging to the following families: Amaranthaceae (Suaeda vera Forssk. ex J.F.Gmel, Salsola vermiculata L., Beta maritima L.), Plumbaginaceae (Limoniastrum monopetalum L. Boiss., Limonium algarvense Erben, Limonium ferulaceum (L.) Chaz), Frankeniaceae (Frankenia laevis (L.) F. Muell. ex Hablitz, Polypogon maritimus Willd), Aizoaceae (Mesembryanthemum crystallinum L., Lampranthus sp.), Tamaricaceae (Tamarix africana L.), Asteraceae (Cotula coronopifolia L.), Poaceae (Sporobolus sp., Phragmites australis L. Trin ex. Steud, Hordeum marinum Huds, Spartina densiflora Brongn, Spartina maritima (Curtis) Fernald, Cyperaceae (Scirpus maritimus L.), and Polygonaceae (Polygonum maritimum L.). Biomass (aboveground organs: leaves and stems) from a minimum of five plants were collected and mixed, samples were dried at 
$40{ }^{\circ} \mathrm{C}$ in an oven for 3 days, milled in a coffee grinder, sifted through a $50 \mu \mathrm{M}$ mesh size standard sieve, and stored at $-20^{\circ} \mathrm{C}$ until needed (maximum of 2 months).

\subsection{Extraction and Fatty Acid Methyl Esters (FAME) Preparation}

Lipids and free FA were converted to the corresponding FAME using previously described protocols [22,23]. In brief, $0.1 \mathrm{~g}$ of dried biomass was mixed with the derivatization solution $(1.5 \mathrm{~mL}$ of methanol/acetyl chloride, 20:1 v/v) and the biomass was disrupted with an IKA Ultra-Turrax disperser, for 2 minutes. Then, $1 \mathrm{~mL}$ of hexane was added and the mixture was heated for 1 hour at $100{ }^{\circ} \mathrm{C}$. Samples were cooled in an ice bath, distilled water $(1 \mathrm{~mL})$ was added and the organic phase was collected and dried with anhydrous sodium sulphate. Finally, the extracts were filtered and stored at $-20^{\circ} \mathrm{C}$ before GC-MS analysis.

\subsection{Determination of FAME Profile by GC-MS}

FAMEs were analyzed on an Agilent GC-MS (Agilent Technologies 6890 Network GC System, 5973 Inert Mass Selective Detector) fitted out with a DB5-MS capillary column ( $25 \mathrm{~m} \times 0.25 \mathrm{~mm}$ internal diameter, $0.25 \mu \mathrm{m}$ film thickness, Agilent Tech), with helium as the carrier gas. Samples were injected at $300^{\circ} \mathrm{C}$ and the temperature profile of the GC oven was the following: $60^{\circ} \mathrm{C}(1 \mathrm{~min}), 30^{\circ} \mathrm{C} \mathrm{min}-1$ to $120^{\circ} \mathrm{C}, 5^{\circ} \mathrm{C}$ min -1 to $250{ }^{\circ} \mathrm{C}$, and $20^{\circ} \mathrm{C} \mathrm{min}-1$ to $300{ }^{\circ} \mathrm{C}$ ( $2 \mathrm{~min}$ ). Identification and quantification of the FAME was done in total ion mode, by comparison with the retention times of the standards, "Supelco ${ }^{\circledR} 37$ Component FAME Mix" (Sigma-Aldrich, Sintra, Portugal) and confirmed by comparison of the MS profile with those from the NIST library (National Institute of Standards and Technology, U. S. Department of Commerce). Quantification was achieved using the total ion mode and single calibration curves for each FAME. Results were expressed as mg/g of dry weight (DW).

\subsection{Statistical Analysis}

The FA profile was carried out in quadruplicate for all studied species. Presented results are expressed as mean \pm standard deviation (SD). Statistical differences among total FAME and FA of the different species were calculated by analysis of variance (ANOVA), after data parametricity assessment, with Statistica 7.0 (StatSoft, Tulsa, OK, USA) and the StatPlus LE 5.8.2 (AnalystSoft, Alexandria, VA, USA) software packages.

\section{Results and Discussion}

\subsection{Total FAME Concentration}

Total FAME concentrations in the studied halophyte plants (Figure 1) ranged from 1.00 to $7.27 \mathrm{mg} / \mathrm{g}$ DW (dry weight). The species S. vermiculata and B. maritima had the highest FAME concentrations amongst all species, with 7.21 and $7.27 \mathrm{mg} / \mathrm{g}$ DW, respectively. Suaeda vera had the lowest FAME content $(1.00 \mathrm{mg} / \mathrm{g} \mathrm{DW})$. This data is within the range of values obtained in previous studies for other halophyte species. Halimione portulacoides (Amaranthaceae), Salicornia europaea (Chenopodiaceae) and Spartina anglica (Poaceae) have shown lower FAME levels, ranging from 0.153 to $0.350 \mathrm{mg} / \mathrm{g}$ [24]. However higher values have also been reported for Crithmum maritimum (Apiaceae; 15.3-21.6 mg/g), for Sesuvium portulacastrum (Aizoaceae) and M. crystallinum (Aizoaceae, approximately $27 \mathrm{mg} / \mathrm{g}$ ) $[17,18,24]$. The levels of FA in plants, either glyco- or halophytes, are strongly influenced not only by intra- and interspecific variations but also by environmental conditions, the latter with a high impact on the lipid composition of plant membranes [18,20]. Moreover, the efficiency of lipid extraction depends on the method of extraction, both in terms of solvent and the types of pretreatment and cell disruption methods [25]. 


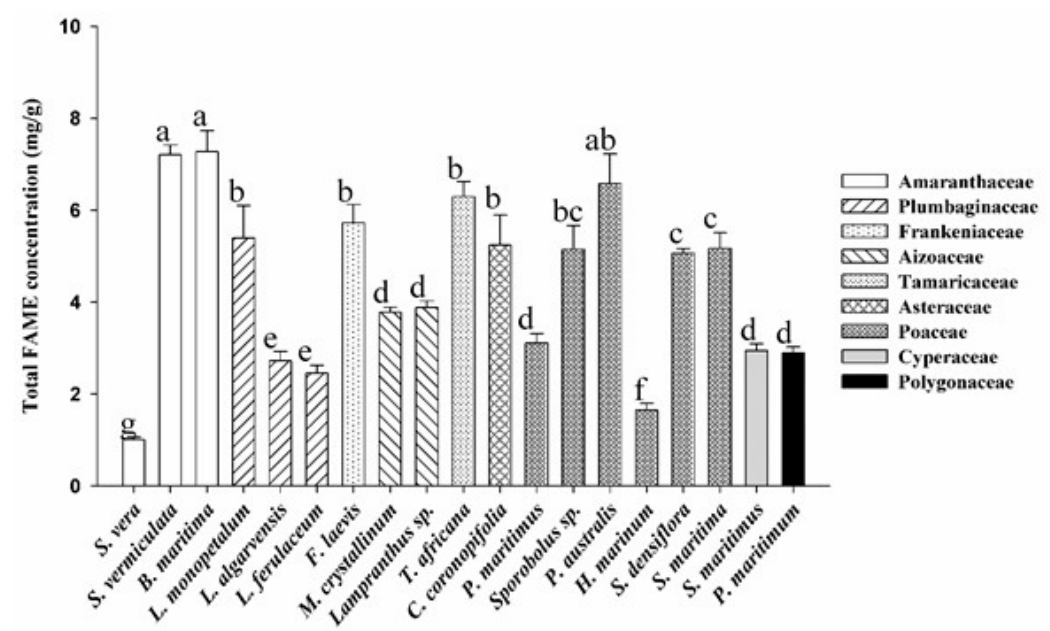

Figure 1. Total fatty acid methyl esters (FAME) concentration ( $\mathrm{mg} / \mathrm{g}, \mathrm{DW})$ of the halophytes studied in this work. Species are grouped by the corresponding family. Solid bars and errors bars represent the average and SD, respectively $(n=4)$.

\subsection{FAME Profiles}

SFA contributed between $24.8 \%$ (C. coronopifolia) and $81.0 \%$ (L. monopetalum) to the total amount of FA, and accounted for more than 50\% of the FAME in eight other species (S. maritimus, P. maritimum, F. laevis, M. crystallinum, Lampranthus sp., T. africana, P. maritimus and L. ferulaceum) of the nineteen species investigated (Tables 1-3). The dominant SFA was palmitic acid (C16:0), which was already previously reported as one of the major FA in halophytes $[17,20]$. Arachidic $(C 20: 0)$, behenic (C22:0), myristic (C14:0) and stearic (C18:0) acids were also present in all studied species. The proportion of MUFA was lower than those of SFA and PUFA in all species and ranged from "below the detection limit" in S. vera to $16.9 \%$ in S. densiflora. The most prevalent MUFA was oleic acid (C18:1). However, in C. coronopifolia, H. marinum and P. australis, palmitoleic (C16:1) and/or eicosenoic acids (C20:1) were predominant. The low proportion of MUFA is consistent with the values reported for other halophytes, such as Carpobrotus edulis and Arthrocnemum macrostachyum [19] or S. maritima [21].

PUFA content ranged from $15.2 \%$ in L. monopetalum to $74.6 \%$ in C. coronopifolia of the total FA, and accounted for more than $50 \%$ of the total FAME in Sporobolus sp., P. australis, H. marimum, S. vera and B. maritima. Linoleic (C18:2n-6) and $\alpha$-linolenic acids (C18:3n-3) are typical of plants [24] and have been reported as the predominant FA, along with palmitic acid, in the halophytes Eichhornia crassipes [26] and in C. maritimum [17]. In this work, all species contained linoleic acid (C18:2n-6), which corresponded to more than $40 \%$ of the total FAME in S. vermiculata, B. maritima, L. algarvense, S. densiflora and S. maritima. The $\alpha$-linolenic acid (C18:3n-3) ranged between $33.5 \%$ and $39.9 \%$ in the FAME profiles of Sporobolus sp., S. vera, P. australis, H. marinum and C. coronopifolia. This FA was not detected in the remaining species, most probably because it was presented in not detectable levels. Linoleic and $\alpha$-linolenic are considered essential PUFA as vertebrates are unable to synthesize them, and thus they must be obtained through diet [15]. Therefore, these PUFA are among the most important types required in both food and feed. In addition, nutritional products with relatively high levels of linoleic and $\alpha$-linolenic PUFA have shown to enrich goat meat with $n$-3 fatty acids, making it a healthier product [27]. C. coronopifolia, S. vera and P. australis displayed relatively high levels of $\alpha$-linolenic acid which, besides being an essential PUFA, has several described beneficial biological effects namely anti-inflammatory activity [28,29], capacity to decrease coronary disease incidence [30] and neuroprotection effects [31]. Linoleic acid has also been described as a bioactive compound with anti-fungal activity [32], besides inhibiting carcinogenesis and atherosclerosis progression [33]. These species also display biological properties that may be of interest for the improvement of both humans and animals, such as antioxidant, antifungal and hepatoprotective [34-37]. Moreover, P. australis also has ethnoveterinary uses against gastrointestinal (anti-diarrheal) and stomach disorders [38-40]. 
Table 1. Fatty acid (FA) profile, expressed in terms of \% of total FA, of species from the families Amaranthaceae (Sueda vera, Salsola vermiculata, Beta maritima), and Plumbaginaceae (Limoniastrum monopetalum, Limonium algarvense, Limonium ferulaceum).

\begin{tabular}{|c|c|c|c|c|c|c|c|}
\hline & & Amaranthaceae & & & Plumbaginaceae & & \\
\hline FA (\%) & Common Name & S. vera & S. vermiculata & B. maritima & L. monopetalum & L. algarvense & L. ferulaceum \\
\hline $\mathrm{C} 12: 0$ & Lauric acid & $*$ & $0.2 \pm 0.0$ & $*$ & $1.4 \pm 0.2$ & $0.6 \pm 0.0$ & $0.8 \pm 0.0$ \\
\hline C14:0 & Myristic acid & $1.9 \pm 0.0$ & $1.0 \pm 0.1$ & $0.6 \pm 0.0$ & $0.7 \pm 0.1$ & $1.8 \pm 0.1$ & $3.3 \pm 0.1$ \\
\hline C15:0 & Pentadecanoic acid & $*$ & $0.3 \pm 0.0$ & $0.3 \pm 0.0$ & $*$ & $*$ & $0.7 \pm 0.0$ \\
\hline $\mathrm{C} 16: 0$ & Palmitic acid & $27.4 \pm 0.1$ & $20.9 \pm 0.8$ & $25.4 \pm 0.3$ & $19.4 \pm 2.3$ & $33.0 \pm 0.2$ & $35.0 \pm 1.0$ \\
\hline C17:0 & Margaric acid & * & $0.5 \pm 0.0$ & $0.3 \pm 0.0$ & $0.5 \pm 0.0$ & * & $0.6 \pm 0.0$ \\
\hline C18:0 & Stearic acid & $3.5 \pm 0.0$ & $3.3 \pm 0.1$ & $2.7 \pm 0.0$ & $11.6 \pm 9.7$ & $4.3 \pm 0.1$ & $3.7 \pm 0.1$ \\
\hline C20:0 & Arachidic acid & $3.5 \pm 0.1$ & $3.4 \pm 0.1$ & $1.1 \pm 1.0$ & $23.3 \pm 3.0$ & $3.2 \pm 0.1$ & $5.5 \pm 0.2$ \\
\hline C21:0 & Henicosanoic acid & * & $0.4 \pm 0.1$ & $*$ & $1.2 \pm 0.2$ & $*$ & $*$ \\
\hline C22:0 & Behenic acid & $6.0 \pm 0.1$ & $5.0 \pm 0.1$ & $2.5 \pm 0.1$ & $16.4 \pm 1.9$ & $2.8 \pm 0.0$ & $8.3 \pm 0.6$ \\
\hline C23:0 & Tricosylic acid & $*$ & $1.6 \pm 0.0$ & $0.5 \pm 0.0$ & $1.7 \pm 0.2$ & $*$ & * \\
\hline C24:0 & Lignoceric acid & * & $2.6 \pm 0.1$ & $1.6 \pm 0.3$ & $4.7 \pm 0.4$ & $2.6 \pm 0.3$ & $4.8 \pm 0.4$ \\
\hline C26:0 & Cerotic acid & * & $1.2 \pm 0.1$ & * & * & $*$ & $*$ \\
\hline$\sum$ SFA & & $42.2 \pm 0.2$ & $40.6 \pm 0.9$ & $34.9 \pm 1.1$ & $81.0 \pm 10.6$ & $48.3 \pm 0.4$ & $62.9 \pm 1.2$ \\
\hline C16:1 & Palmitoleic acid & $*$ & $2.0 \pm 0.0$ & $0.4 \pm 0.3$ & * & $0.5 \pm 0.4$ & $1.7 \pm 0.1$ \\
\hline C18:1 & Oleic acid & * & $9.8 \pm 0.3$ & $12.6 \pm 0.1$ & $3.8 \pm 0.4$ & $8.8 \pm 0.1$ & $7.3 \pm 0.2$ \\
\hline C20:1 & Eicosenoic acid & * & * & $0.4 \pm 0.01$ & * & $*$ & * \\
\hline$\sum$ MUFA & & * & $11.8 \pm 0.2$ & $13.4 \pm 0.3$ & $3.8 \pm 0.4$ & $9.4 \pm 0.4$ & $9.0 \pm 0.2$ \\
\hline $\bar{C} 18: 2(n-6)$ & Linoleic acid & $22.0 \pm 0.7$ & $47.6 \pm 1.0$ & $51.4 \pm 0.8$ & $15.2 \pm 1.6$ & $42.3 \pm 0.2$ & $28.2 \pm 0.3$ \\
\hline $\mathrm{C} 16: 3(\mathrm{n}-3)$ & Hexadecatrienoic acid & * & * & $0.2 \pm 0.0$ & $*$ & $*$ & $*$ \\
\hline C18:3(n-3) & $\alpha$-linolenic acid & $35.8 \pm 0.6$ & * & $*$ & * & * & * \\
\hline$\sum$ PUFA & & $57.8 \pm 1.0$ & $47.6 \pm 1.0$ & $51.7 \pm 0.8$ & $15.2 \pm 1.6$ & $42.3 \pm 0.2$ & $28.2 \pm 0.3$ \\
\hline $\bar{\Sigma}$ PUFA/ $\Sigma$ SFA & & 1.4 & 1.2 & 1.5 & 1.9 & 0.9 & 0.4 \\
\hline$n-6 / n-3$ & & 0.6 & - & - & - & - & - \\
\hline
\end{tabular}


Table 2. Fatty acid (FA) profile, expressed in terms of \% of total FA, of species from the families Frankeniaceae (Frankenia laevis), Aizoaceae (Mesembryanthemum crystallinum, Lampranthus sp.), Tamaricaceae (Tamarix africana) and Asteraceae (Cotula coronopifolia).

\begin{tabular}{|c|c|c|c|c|c|c|}
\hline & & Frankeniaceae & Aizoaceae & & Tamaricaceae & Asteraceae \\
\hline FA $(\%)$ & Common Name & F. laevis & M. crystallinum & Lampranthus sp. & T. africana & C. coronopifolia \\
\hline C12:0 & Lauric acid & $2.7 \pm .0 .1$ & $0.3 \pm 0.0$ & $1.4 \pm 0.1$ & $1.3 \pm 0.1$ & $0.2 \pm 0.1$ \\
\hline C14:0 & Myristic acid & $3.7 \pm 0.1$ & $2.3 \pm 0.1$ & $3.4 \pm 0.1$ & $4.0 \pm 0.2$ & $1.0 \pm 0.1$ \\
\hline C15:0 & Pentadecanoic acid & $0.2 \pm 0.2$ & $*$ & $0.5 \pm 0.3$ & $0.3 \pm 0.0$ & $0.3 \pm 0.0$ \\
\hline C16:0 & Palmitic acid & $18.7 \pm 0.4$ & $26.1 \pm 0.4$ & $14.3 \pm 0.5$ & $25.6 \pm 0.6$ & $17.5 \pm 0.6$ \\
\hline C17:0 & Margaric acid & $0.5 \pm 0.0$ & $0.5 \pm 0.0$ & $0.5 \pm 0.3$ & $0.4 \pm 0.0$ & $0.2 \pm 0.2$ \\
\hline C18:0 & Stearic acid & $2.5 \pm 0.1$ & $3.3 \pm 0.1$ & $3.0 \pm 0.1$ & $3.9 \pm 0.0$ & $1.6 \pm 0.1$ \\
\hline C20:0 & Arachidic acid & $5.2 \pm 0.6$ & $10.5 \pm 0.1$ & $18.9 \pm 0.9$ & $3.6 \pm 0.2$ & $0.6 \pm 0.5$ \\
\hline C21:0 & Henicosanoic acid & $*$ & $0.8 \pm 0.0$ & $1.2 \pm 0.1$ & $*$ & $*$ \\
\hline $\mathrm{C} 22: 0$ & Behenic acid & $9.8 \pm 0.5$ & $12.0 \pm 0.1$ & $18.9 \pm 0.9$ & $6.1 \pm 0.5$ & $1.4 \pm 0.1$ \\
\hline C23:0 & Tricosylic acid & * & $1.6 \pm 0.0$ & $*$ & $2.1 \pm 1.0$ & $*$ \\
\hline C24:0 & Lignoceric acid & $17.6 \pm 1.1$ & $5.9 \pm 1.2$ & $6.2 \pm 1.1$ & $4.1 \pm 2.0$ & $1.9 \pm 0.1$ \\
\hline $\mathrm{C} 26: 0$ & Cerotic acid & $2.5 \pm 0.1$ & $*$ & $*$ & $*$ & $*$ \\
\hline$\sum$ SFA & & $70.1 \pm 1.5$ & $63.5 \pm 1.3$ & $68.3 \pm 1.3$ & $51.6 \pm 2.4$ & $24.8 \pm 0.8$ \\
\hline C16:1 & Palmitoleic acid & $1.6 \pm 0.5$ & $0.9 \pm 0.0$ & $*$ & $0.9 \pm 0.8$ & $0.6 \pm 0.0$ \\
\hline C18:1 & Oleic acid & $8.8 \pm 0.3$ & $13.8 \pm 0.1$ & $6.9 \pm 0.2$ & $11.1 \pm 0.2$ & $*$ \\
\hline C20:1 & Eicosenoic acid & $0.3 \pm 0.0$ & $*$ & $*$ & $0.3 \pm 0.0$ & $*$ \\
\hline$\sum$ MUFA & & $10.8 \pm 0.6$ & $14.7 \pm 0.1$ & $6.9 \pm 0.2$ & $12.3 \pm 0.8$ & $0.6 \pm 0.0$ \\
\hline C18:2(n-6) & Linoleic acid & $19.1 \pm 1.0$ & $19.6 \pm 0.3$ & $24.8 \pm 1.0$ & $36.2 \pm 0.3$ & $34.7 \pm 1.0$ \\
\hline$C 16: 3(n-3)$ & Hexadecatrienoic acid & * & $2.2 \pm 0.1$ & $*$ & * & * \\
\hline C18:3(n-3) & $\alpha$-linolenic acid & * & $*$ & * & $*$ & $39.9 \pm 0.2$ \\
\hline$\sum$ PUFA & & $19.1 \pm 1.0$ & $21.8 \pm 0.3$ & $24.8 \pm 1.0$ & $36.2 \pm 0.3$ & $74.6 \pm 1.0$ \\
\hline$\sum$ PUFA $/ \sum$ SFA & & 0.3 & 0.3 & 0.4 & 0.7 & 3.0 \\
\hline$n-6 / n-3$ & & - & - & - & - & 0.9 \\
\hline
\end{tabular}


Table 3. Fatty acid (FA) acid profile, expressed in terms of \% of total FA, of species from the order Poales, belonging to three different families: Poaceae (Sporobolus sp., Phragmites australis, Hordeum marinum, Spartina densiflora, S. maritima), Cyperaceae (Scirpus maritimus) and Polygonaceae (Polygonum maritimum).

\begin{tabular}{|c|c|c|c|c|c|c|c|c|c|}
\hline & & Poaceae & & & & & & Cyperaceae & Polygonaceae \\
\hline FA (\%) & Common name & P. maritimus & Sporobolus sp. & P. australis & H. marinum & S. densiflora & S. maritima & S. maritimus & P. maritimum \\
\hline C12:0 & Lauric acid & $0.8 \pm 0.0$ & $1.2 \pm 0.0$ & $0.8 \pm 0.0$ & $0.5 \pm 0.0$ & $0.7 \pm 0.0$ & $0.7 \pm 0.0$ & $3.1 \pm 0.1$ & $0.7 \pm 0.0$ \\
\hline C14:0 & Myristic acid & $2.0 \pm 0.1$ & $1.8 \pm 0.1$ & $2.0 \pm 0.1$ & $1.6 \pm 0.1$ & $1.5 \pm 0.0$ & $1.5 \pm 0.1$ & $5.4 \pm 0.2$ & $4.2 \pm 0.2$ \\
\hline C15:0 & Pentadecanoic acid & $1.0 \pm 0.0$ & $0.4 \pm 0.0$ & $0.3 \pm 0.0$ & $*$ & $0.5 \pm 0.0$ & $0.5 \pm 0.0$ & $1.1 \pm 0.0$ & $0.5 \pm 0.0$ \\
\hline C16:0 & Palmitic acid & $36.4 \pm 1.1$ & $19.7 \pm 1.0$ & $20.7 \pm 0.4$ & $21.6 \pm 0.3$ & $17.9 \pm 0.0$ & $17.6 \pm 0.6$ & $40.1 \pm 0.9$ & $27.8 \pm 0.1$ \\
\hline C17:0 & Margaric acid & $0.9 \pm 0.0$ & $*$ & $0.5 \pm 0.0$ & $*$ & $0.5 \pm 0.0$ & $0.5 \pm 0.0$ & $1.1 \pm 0.0$ & $0.4 \pm 0.3$ \\
\hline C18:0 & Stearic acid & $4.6 \pm 0.2$ & $2.5 \pm 0.3$ & $0.8 \pm 1.3$ & $1.8 \pm 0.1$ & $2.4 \pm 0.0$ & $2.2 \pm 0.1$ & $4.4 \pm 0.1$ & $3.3 \pm 0.0$ \\
\hline C20:0 & Arachidic acid & $2.4 \pm 0.0$ & $4.2 \pm 0.4$ & $2.9 \pm 0.1$ & $2.4 \pm 0.1$ & $6.7 \pm 0.1$ & $7.0 \pm 0.3$ & $3.5 \pm 0.1$ & $7.5 \pm 0.2$ \\
\hline C21:0 & Henicosanoic acid & $0.4 \pm 0.3$ & $*$ & $0.5 \pm 0.0$ & $*$ & $*$ & $*$ & $*$ & $0.7 \pm 0.0$ \\
\hline C23:0 & Tricosylic acid & $*$ & * & $0.7 \pm 0.0$ & $*$ & $2.0 \pm 0.6$ & $1.1 \pm 0.7$ & $1.7 \pm 0.1$ & $1.9 \pm 0.3$ \\
\hline C24:0 & Lignoceric acid & $3.5 \pm 0.4$ & $3.3 \pm 0.4$ & $2.5 \pm 0.4$ & * & $3.9 \pm 0.0$ & $4.4 \pm 0.7$ & $5.9 \pm 0.4$ & $6.6 \pm 0.3$ \\
\hline C26:0 & Cerotic acid & $*$ & $*$ & $*$ & $*$ & $1.5 \pm 0.0$ & $0.8 \pm 0.9$ & $2.5 \pm 0.2$ & * \\
\hline$\sum$ SFA & & $54.2 \pm 2.7$ & $36.9 \pm 1.2$ & $34.0 \pm 1.5$ & $29.7 \pm 0.4$ & $40.2 \pm 0.7$ & $38.9 \pm 1.5$ & $72.3 \pm 1.0$ & $64.2 \pm 0.6$ \\
\hline C16:1 & Palmitoleic acid & $2.4 \pm 0.2$ & * & $1.5 \pm 0.1$ & $1.1 \pm 0.0$ & $1.5 \pm 0.0$ & $1.6 \pm 0.2$ & * & $2.1 \pm 0.0$ \\
\hline C18:1 & Oleic acid & $10.7 \pm 0.3$ & $0.8 \pm 0.0$ & $*$ & $0.8 \pm 0.0$ & $14.7 \pm 0.2$ & $14.0 \pm 0.7$ & $6.8 \pm 0.2$ & $9.8 \pm 0.0$ \\
\hline C20:1 & Eicosenoic acid & $*$ & * & $0.1 \pm 0.1$ & * & $0.7 \pm 0.0$ & $0.9 \pm 0.1$ & * & * \\
\hline$\sum$ MUFA & & $13.1 \pm 0.3$ & $0.7 \pm 0.0$ & $1.6 \pm 0.1$ & $1.9 \pm 0.0$ & $16.9 \pm 0.1$ & $16.5 \pm 0.6$ & $6.8 \pm 0.2$ & $11.8 \pm 0.0$ \\
\hline C18:2(n-6) & Linoleic acid & $32.7 \pm 0.8$ & $28.8 \pm 0.6$ & $26.5 \pm 0.4$ & $34.8 \pm 0.7$ & $42.4 \pm 0.7$ & $44.1 \pm 0.6$ & $20.9 \pm 1.7$ & $24.0 \pm 0.1$ \\
\hline C20:2(n-6) & Eicosadienoic acid & * & * & * & * & $0.5 \pm 0.0$ & $0.5 \pm 0.0$ & * & * \\
\hline$\sum$ PUFA & & $32.7 \pm 0.8$ & $62.3 \pm 1.8$ & $64.4 \pm 1.1$ & $68.4 \pm 0.7$ & $42.9 \pm 0.7$ & $44.6 \pm 0.6$ & $20.9 \pm 1.8$ & $24.0 \pm 0.1$ \\
\hline $\begin{array}{l}\sum_{\text {SFA }} \text { PUFA/ } \Sigma \\
\text {. }\end{array}$ & & 0.6 & 1.7 & 1.9 & 2.3 & 1.1 & 1.1 & 0.3 & 0.4 \\
\hline$n-6 / n-3$ & & - & 0.9 & 0.7 & 1.0 & - & - & - & - \\
\hline
\end{tabular}

* below the detection limit; $n=4$. 


\subsection{Less Common FAME}

Less common FAs were also found in a limited number of halophytes. Eicosadienoic acid (C20:2n-6) was only detected in Spartina species (S. densiflora and S. maritima; Table 3), and not detected in the other studied species. Another example of unusual FA is hexadecatrienoic (C16:3n-3) acid, which was detected in B. maritima and M. crystallinum. These results confirm earlier findings that C16:3n-3 is typically not detectable in Poaceae and Polygonaceae species and is either not detectable or present only in trace amounts in the Amaranthaceae family [41]. However, the fact that we were able to detect C16:3n-3 in M. crystallinum and B. maritima is important as most angiosperms, which are called "18:3 plants", fail to accumulate significant amounts of C16:3 [41]. Consequently, it would be worthwhile to ascertain in future studies how often this phenotype occurs among halophytes.

\subsection{Potential Implications for Human and Animal Nutrition}

It is well established that excessive SFA intake increases low-density lipoprotein (LDL) cholesterol, a strong risk factor for cardiovascular disease. Several lines of research showed that consumption of higher PUFA levels in relation to SFA decreases this risk. WHO/FAO guidelines for a balanced diet suggest PUFA/SFA ratio to be above 0.4 and the British Department of Health recommend 0.45 or higher [42]. From this aspect, fourteen species of the nineteen halophytes under study (S. vera, S. vermiculata, B. maritima, L. monopetalum, L. algarvense, L. ferulaceum, T. africana, C. coronopifolia, P. maritimus, Sporobolus sp., P. australis, H. marinum, S. densiflora and S. maritima) showed favourable PUFA/SFA ratios (Tables 1-3), with the best ratio displayed by C. coronopifolia (3.0), followed by H. marimum (2.3), P. australis (1.9) and L. monopetalum (1.9).

It has been estimated that the present Western diet is deficient in n-3 fatty acids, with a ratio of n- 6 to n-3 of 15-20/1, instead of $1 / 1$ as is the case with wild animals and presumably human beings [43]. Nutritional advice for today's n-6/n-3 PUFA ratio is less than 4 [44]. The n-6/n-3 PUFA ratios determined in this study ranged between 0.5 in $S$. vera and 1.1 in H. marinum. P. australis, Sporobolus sp., C. coronopifolia and H. marimum presented n-6/n-3 ratios of $0.7,0.9,0.9$ and 1.0 respectively, which are within the values recommended.

Taken together, our results suggest that $C$. coronopifolia, P. australis and S. vera displayed the best FA nutritional profiles and could be considered additional sources of natural ingredients for food and feed with health improving properties. These species could be potentially included in food products or directly consumed by humans. In addition, these halophytes could also be included as forage and/or fodder with the main goal of feeding monogastric animals. Unlike polygastric animals (e.g. bovines), monogastric animals, such as pigs, rabbits and horses, lack the bacteria that hydrogenate dietary PUFA into SFA. Thus, it is well known that pig meat can contain higher levels of PUFA as compared to beef and these levels can be highly influenced by the PUFA present in the feed, which in turn impacts on human health [45]. However, caution must be used when including halophytes into feed or food as halophytes present antinutritional factors as chemical defences. These have to be evaluated and taken into account due to toxicity issues. However, the toxicity rate is also affected by several factors such as the rate of ingestion, type and rate of microbial transformation of such metabolites [46]. Environmental and soil conditions, as well as seasons, may also influence the FA content. Southern Portugal displays a mild Mediterranean climate but with the lowest mean annual precipitation in the country [47]. That fact, combined with the proximity to the Sahara, makes the region even more prone to desertification, confirming the need for this kind of studies. The soil is based on calcareous and sedimentary rocks (sand, gravel, clay, sandstone, conglomerate) where glycophyte agriculture is difficult to thrive, making halophytes a sustainable agricultural option. To the best of our knowledge, there is no information on the optimal time to harvest the species included in this study, regarding yield, nutritional value, texture, taste or flavour. Therefore, this study can be used as a reference for the season in June. This work opens novel research lines concerning the use of plants thriving on marginal soils that can improve only the local economy, in a sustainable way. 


\section{Conclusions}

This work is the first comprehensive evaluation of the composition of FA of nineteen halophyte species. C. coronopifolia, P. australis and S. vera stood out for their $\alpha$-linolenic acid contents, as well as their high PUFA/SFA and low n-6/n-3 PUFA ratios, suggesting potential applications in food and/or feed industry. This information, coupled with that gathered from the literature of the traditional uses and biological properties of such species, suggest that they can be considered beneficial as sources of natural products to be included in human nutrition, or in forage and/or fodder. Also, a positive impact on human health could be obtained by the consumption of monogastric animals fed with the above-mentioned halophytes. Additional studies are in progress aiming to establish the complete nutritional profile of said species, including antinutritional and toxic components, along with relevant functional properties. Moreover, different extraction methods are being tested to optimize the lipids recovery from selected species. All in all, this work opens novel research lines concerning the sustainable exploitation of salt-tolerant plants, adapted to salinized marginal soils, as sources of food and/or feed ingredients, with predictable benefits for human well-being and the local economy.

Author Contributions: C.V.-D. designed the research, collected the samples, formally analyzed the data and wrote the original manuscript; F.F., M.J.R., C.P., E.R. collected and analyzed the samples; L.C. acquired funding, designed the research, edited and reviewed the manuscript.

Funding: This research was funded by the Foundation for Science and Technology (FCT) and the Portuguese National Budget through the XtremeBio (PTDC/MAR-EST/4346/2012), GreenVet (ALG-01-0145-FEDER-028876) and UID/Multi/04326/2019 projects. The research was also funded by FCT doctoral research fellowships (SFRH/BD/81425/2011 and SFRH/BD/116604/2016, for Catarina Vizetto-Duarte and Maria João Rodrigues, respectively). Luísa Custódio was supported by the FCT Investigator Programme (IF/00049/2012) and FCT Scientific Employment Stimulus (CEECIND/00425/2017).

Acknowledgments: The authors thank Hugo Pereira (CCMAR) for technical support during FA analysis. Special thanks to Prof. Rui Bessa (Faculty of Veterinary Medicine, University of Lisbon) for critically reading the manuscript.

Conflicts of Interest: The authors declare no conflict of interest.

\section{References}

1. Daliakopoulos, I.N.; Tsanis, I.K.; Koutroulis, A.; Kourgialas, N.N.; Varouchakis, A.E.; Karatzas, G.P.; Ritsema, C.J. The threat of soil salinity: A European scale review. Sci. Total Environ. 2016, 573, 727-739. [CrossRef]

2. FAO. Available online: http://www.grida.no/resources/5906 (accessed on 7 September 2018).

3. Branco, J.; Oliveria, M.; Ferreira, R.; Povoa, O. Desertification in Portugal: Causes, consequences and possible solutions. In Atas do I Congresso de Estudos Rurais do Norte Alentejano; Instituto Politécnico de Portalegre: Portalegre, Portugal, 2012.

4. Flowers, T.J.; Colmer, T.D. Salinity tolerance in halophytes. New Phytol. 2008, 179, 945-963. [CrossRef]

5. Panta, S.; Flowers, T.; Lane, P.; Doyle, R.; Haros, G.; Shabala, S. Halophyte agriculture: Success stories. Environ. Exp. Bot. 2014, 107, 71-83. [CrossRef]

6. Ventura, Y.; Eshel, A.; Pasternak, D.; Sagi, M. The development of halophyte-based agriculture: Past and present. Ann. Bot. 2015, 115, 529-540. [CrossRef]

7. Ksouri, R.; Megdiche, W.; Debez, A.; Falleh, H.; Grignon, C.; Abdelly, C. Salinity effects on polyphenol content and antioxidant activities in leaves of the halophyte Cakile maritima. Plant Physiol. Biochem. 2007, 45, 244-249. [CrossRef]

8. Cheeseman, J.M. The evolution of halophytes, glycophytes and crops, and its implications for food security under saline conditions. New Phytol. 2015, 206, 557-570. [CrossRef]

9. Barreira, L.; Resek, E.; Rodrigues, M.J.; Rocha, M.I.; Pereira, H.; Bandarra, N.; da Silva, M.M.; Varela, J.; Custodio, L. Halophytes: Gourmet food with nutritional health benefits? J. Food Compos. Anal. 2017, 59, 35-42. [CrossRef]

10. El Shaer, H.M. Halophytes and salt-tolerant plants as potential forage for ruminants in the Near East region. Small Rumin. Res. 2010, 91, 3-12. [CrossRef] 
11. Zárate, R.; El Jaber-Vazdekis, N.; Tejera, N.; Pérez, J.A.; Rodríguez, C. Significance of long chain polyunsaturated fatty acids in human health. Clin. Transl. Med. 2017, 6, 25. [CrossRef]

12. Abedi, E.; Sahari, M.A. Long-chain polyunsaturated fatty acid sources and evaluation of their nutritional and functional properties. Food Sci. Nutr. 2014, 2, 443-463. [CrossRef]

13. Conway, M.C.; Mulhern, M.S.; McSorley, E.M.; van Wijngaarden, E.; Strain, J.J.; Myers, G.J.; Davidson, P.W.; Shamlaye, C.F.; Yeates, A.J. Dietary determinants of polyunsaturated fatty acid (PUFA) status in a high fish-eating cohort during pregnancy. Nutrients 2018, 10, 927. [CrossRef]

14. Van Tran, L.; Malla, B.A.; Kumar, S.; Tyagi, A.K. Polyunsaturated fatty acids in male ruminant reproduction-A Review. Asian Australas. J. Anim. Sci. 2017, 30, 622-637. [CrossRef]

15. Castro, L.F.C.; Monroig, O.; Leaver, M.J.; Wilson, J.; Cunha, I.; Tocher, D.R. Functional desaturase Fads1 (Delta 5) and Fads2 (Delta 6) orthologues evolved before the origin of jawed vertebrates. PLoS ONE 2012, 7, e31950. [CrossRef]

16. Wu, D.; Lewis, E.D.; Pae, M.; Meydani, S.N. Nutritional modulation of immune function: analysis of evidence, mechanisms, and clinical relevance. Front. Immunol. 2018, 9, 3160. [CrossRef]

17. Ben Hamed, K.; Ben Youssef, N.; Ranieri, A.; Zarrouk, M.; Abdelly, C. Changes in content and fatty acid profiles of total lipids and sulfolipids in the halophyte Crithmum maritimum under salt stress. J. Plant Physiol. 2005, 162, 599-602. [CrossRef]

18. Nouairi, I.; Ghnaya, T.; Ben Youssef, N.; Zarrouk, M.; Habib Ghorbel, M. Changes in content and fatty acid profiles of total lipids of two halophytes: Sesuvium portulacastrum and Mesembryanthemum crystallinum under cadmium stress. J. Plant Physiol. 2006, 163, 1198-1202. [CrossRef]

19. Custódio, L.; Ferreira Ana, C.; Pereira, H.; Silvestre, L.; Vizetto-Duarte, C.; Barreira, L.; Rauter Amélia, P.; Alberício, F.; Varela, J. The marine halophytes Carpobrotus edulis L. and Arthrocnemum macrostachyum L. are potential sources of nutritionally important PUFAs and metabolites with antioxidant, metal chelating and anticholinesterase inhibitory activities. Bot. Mar. 2012, 55, 281-288. [CrossRef]

20. Tsydendambaev, V.D.; Ivanova, T.V.; Khalilova, L.A.; Kurkova, E.B.; Myasoedov, N.A.; Balnokin, Y.V. Fatty acid composition of lipids in vegetative organs of the halophyte Suaeda altissima under different levels of salinity. Russ. J. Plant Physiol. 2013, 60, 661-671. [CrossRef]

21. Duarte, B.; Carreiras, J.; Pérez-Romero, J.A.; Mateos-Naranjo, E.; Redondo-Gómez, S.; Matos, A.R.; Marques, J.C.; Caçador, I. Halophyte fatty acids as biomarkers of anthropogenic-driven contamination in Mediterranean marshes: Sentinel species survey and development of an integrated biomarker response (IBR) index. Ecol. Indic. 2018, 87, 86-96. [CrossRef]

22. Lepage, G.; Roy, C.C. Improved recovery of fatty-acid through direct trans-esterification without prior extraction or purification. J. Lipid Res. 1984, 25, 1391-1396.

23. Vizetto-Duarte, C.; Custodio, L.; Acosta, G.; Lago, J.H.G.; Morais, T.R.; de Sousa, C.B.; Gangadhar, K.N.; Rodrigues, M.J.; Pereira, H.; Lima, R.T.; et al. Can macroalgae provide promising anti-tumoral compounds? A closer look at Cystoseira tamariscifolia as a source for antioxidant and anti-hepatocarcinoma compounds. PeerJ 2016, 4, e1704. [CrossRef]

24. Meziane, T.; Bodineau, L.; Retiere, C.; Thoumelin, G. The use of lipid markers to define sources of organic matter in sediment and food web of the intertidal salt-marsh-flat ecosystem of Mont-Saint-Michel Bay, France. J. Sea Res. 1997, 38, 47-58. [CrossRef]

25. Ryckebosch, E.; Muylaert, K.; Foubert, I. Optimization of an analytical procedure for extraction of lipids from microalgae. J. Am. Oil Chem. Soc. 2012, 89, 189-198. [CrossRef]

26. Arayana, G.L.; Rao, K.S.; Pantulu, A.J.; Thyagarajan, G. Composition of lipids in roots, stalks, leaves and flowers of Eichhornia crassipes (Mart.) Solms. Aquat. Bot. 1984, 20, 219-227. [CrossRef]

27. Ebrahimi, M.; Rajion, M.A.; Goh, Y.M. Effects of oils rich in linoleic and $\alpha$-linolenic acids on fatty acid profile and gene expression in goat meat. Nutrients 2014, 6, 3913-3928. [CrossRef]

28. Ren, J.; Chung, S.H. Anti-inflammatory effect of alpha-linolenic acid and its mode of action through the inhibition of nitric oxide production and inducible nitric oxide synthase gene expression via NF-kappaB and mitogen-activated protein kinase pathways. J. Agric. Food Chem. 2007, 55, 5073-5080. [CrossRef]

29. Ren, J.; Han, E.J.; Chung, S.H. In vivo and in vitro anti-inflammatory activities of alpha-linolenic acid isolated from Actinidia polygama fruits. Arch. Pharmacal Res. 2007, 30, 708-714. [CrossRef]

30. Connor, W.E. Importance of n-3 fatty acids in health and disease. Am. J. Clin. Nutr. 2000, 71, 171s-175s. [CrossRef] 
31. Lauritzen, I.; Blondeau, N.; Heurteaux, C.; Widmann, C.; Romey, G.; Lazdunski, M. Polyunsaturated fatty acids are potent neuroprotectors. EMBO J. 2000, 19, 1784-1793. [CrossRef]

32. Walters, D.; Raynor, L.; Mitchell, A.; Walker, R.; Walker, K. Antifungal activities of four fatty acids against plant pathogenic fungi. Mycopathologia 2004, 157, 87-90.

33. Pariza, M.W.; Park, Y.; Cook, M.E. Mechanisms of action of conjugated linoleic acid: Evidence and speculation. Proc. Soc. Exp. Biol. Med. 2000, 223, 8-13. [CrossRef]

34. Kether, F.B.H.; Mahjoub, M.A.; Mahjoub, S.A.; Salah, K.B.; Helal, A.N.; Mighri, Z. Chemical composition, in vitro antifungal and antioxidant activities of essential oil from Cotula coronopifolia L. growing in Tunisia. Afr. J. Microbiol. Res. 2012, 6, 4388-4395.

35. Chen, S.; Ju, M.L.; Luo, Y.; Chen, Z.J.; Zhao, C.P.; Zhou, Y.; Fu, J. Hepatoprotective and antioxidant activities of the aqueous extract from the rhizome of Phragmites australis. Z. Nat. C 2013, 68, 439-444.

36. Sellal, A.; Belattar, R.; Bouzidi, A. Heavy metals chelating ability and antioxidant activity of Phragmites australis stems extracts. J. Ecol. Eng. 2019, 20, 116-123.

37. Mohammed, H.A.; ESBelkhaer, A.; Abdellatif, A.G. Phytochemical and antioxidant screening of Suaeda vera L. growing in Libya. Int. J. Pharm. Res. Sch. 2014, 3, 891-896.

38. Uncini Manganelli, R.E.; Camangi, F.; Tomei, P.E. Curing animals with plants: traditional usage in Tuscany (Italy). J. Ethnopharmacol. 2001, 78, 171-191. [CrossRef]

39. Viegi, L.; Pieroni, A.; Guarrera, P.M.; Vangelisti, R. A review of plants used in folk veterinary medicine in Italy as basis for a databank. J. Ethnopharmacol. 2003, 89, 221-244. [CrossRef]

40. Menale, B.; Muoio, R. Use of medicinal plants in the South-Eastern area of the Partenio Regional Park (Campania, Southern Italy). J. Ethnopharmacol. 2014, 153, 297-307. [CrossRef]

41. Mongrand, S.; Bessoule, J.J.; Cabantous, F.; Cassagne, C. The C16:3 \C18:3 fatty acid balance in photosynthetic tissues from 468 plant species. Phytochemistry 1998, 49, 1049-1064. [CrossRef]

42. Ivanov, D.S.; Levic', J.D.; Sredanovic', S.A. Fatty acid composition of various soybean products. Food Feed Res. 2010, 37, 65-70.

43. Simopoulos, A.P. The importance of the omega-6/omega-3 fatty acid ratio in cardiovascular disease and other chronic diseases. Exp. Biol. Med. 2008, 233, 674-688. [CrossRef]

44. Scollan, N.; Hocquette, J.F.; Nuernberg, K.; Dannenberger, D.; Richardson, I.; Moloney, A. Innovations in beef production systems that enhance the nutritional and health value of beef lipids and their relationship with meat quality. Meat Sci. 2006, 74, 17-33. [CrossRef]

45. Bourre, J.M. Where to find omega-3 fatty acids and how feeding animals with diet enriched in omega-3 fatty acids to increase nutritional value of derived products for human: What is actually useful? J. Nutr. Health Aging 2005, 9, 232-242.

46. Abd El-Hack, M.E.; Samak, D.H.; Noreldin, A.E.; Arif, M.; Yaqoob, H.S.; Swelum, A.A. Towards saving freshwater: Halophytes as unconventional feedstuffs in livestock feed: A review. Environ. Sci. Pollut. Res. 2018, 25, 14397-14406. [CrossRef]

47. Inácio, M.; Pereira, V.; Pinto, M. The Soil Geochemical Atlas of Portugal: Overview and applications. J. Geochem. Explor. 2008, 98, 22-33. [CrossRef]

(C) 2019 by the authors. Licensee MDPI, Basel, Switzerland. This article is an open access article distributed under the terms and conditions of the Creative Commons Attribution (CC BY) license (http://creativecommons.org/licenses/by/4.0/). 